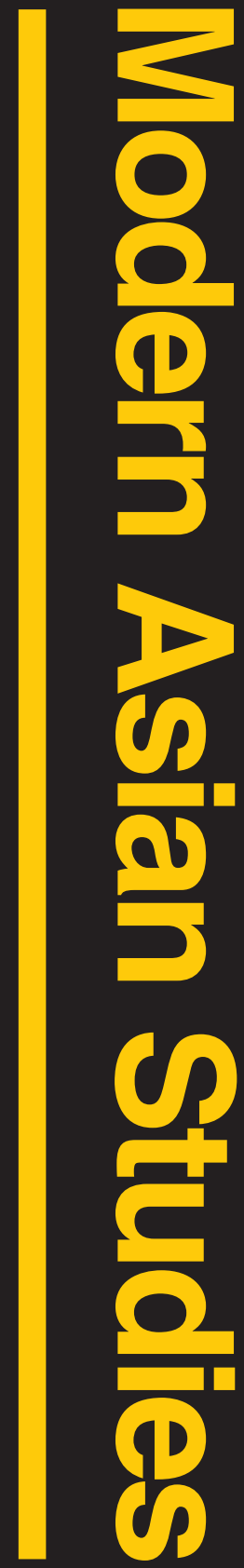

VOLUME 50 PART 3 MAY 2016

ISSN 0026-749X

\title{
CELEBRATING 50 YEARS
}

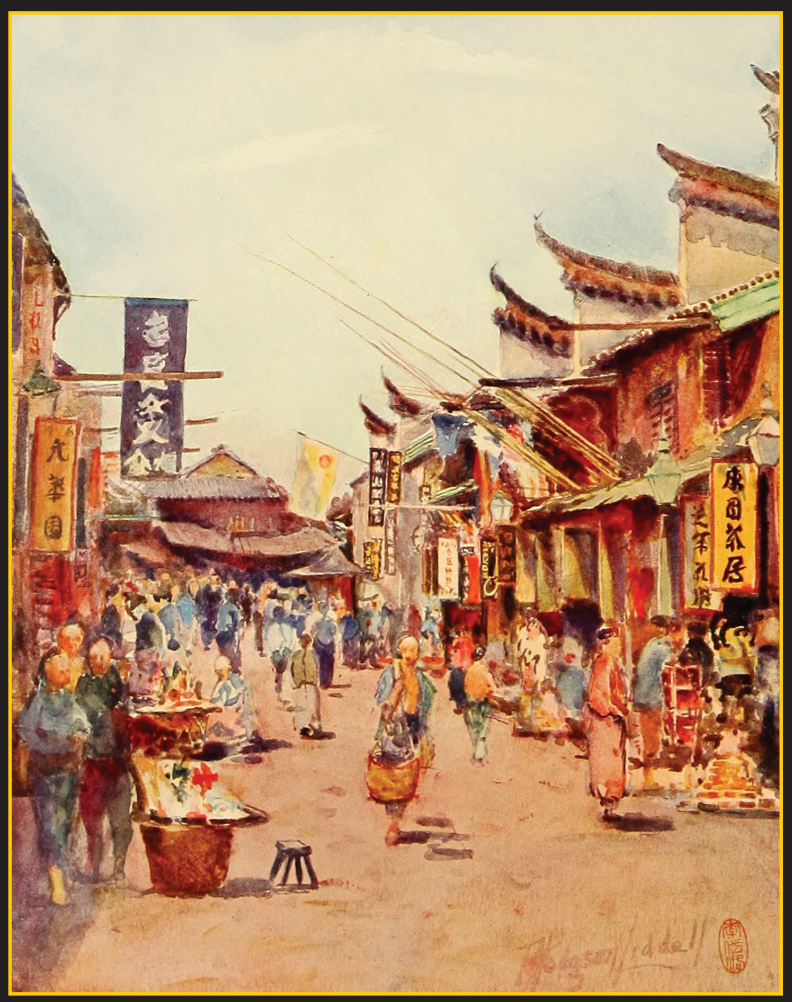




\section{assogiate editor: Norbert Peabody, University of Cambridge \\ EXEGUTIVE COMMITTEE}

Seema Alavi, University of Delhi

Timothy Harper, University of Cambridge

Caroline Humphrey, University of Cambridge

Heonik Kwon, University of Cambridge
James Laidlaw, University of Cambridge

Charles Schencking, University of Hong Kong

Hans Van de Ven, University of Cambridge

David Washbrook, University of Cambridge

\section{EDITORIAL BOARD}

Shahid Amin, University of Delhi

Sunil Amrith, Harvard University

Sumantra Bose, The London School of Economics \& Political Science

Uradyn E. Bulag, University of Cambridge

Prasenjit Duara, National University of Singapore

Richard Eaton, University of Arizona

Wang Gungwu, National University of Singapore

Farhat Hasan, University of Delhi

Engseng Ho, Duke University

Sunil Khilnani, King's College London

Victor T. King, University of Leeds

Barak Kushner, University of Cambridge

Michael Laffan, Princeton University

Victor Lieberman, University of Michigan

Claude Markovits, Centre National de la Recherche Scientifique, Paris
Magnus Marsden, University of Sussex

Rana Mitter, University of Oxford

Deepak Nayyar, Jawaharlal Nehru University

Tirthankar Roy, University of London

Samita Sen, Fadavpur University

Ornit Shani, University of Haifa

Naoko Shimazu, University of London

Eric Tagliacozzo, Cornell University

Robert Travers, Cornell University

G. J. W.-L. Wee, Nanyang Technological University

Thongchai Winichakul, University

of Wisconsin-Madison

Tan Tai Yong, National University of Singapore

Yangwen Zheng, University of Manchester

EMERITUS EDITOR

Gordon Johnson, University of Cambridge

Modern Asian Studies (ISSN 0026-749x) is published six times a year by Cambridge University Press, Journals Fulfilment Department, UPH, Shaftesbury Road, Cambridge CB2 8BS, UK, and 32 Avenue of the Americas, New York, New York 10013, USA. The subscription (excluding VAT but including delivery by air where appropriate), plus electronic access to institutional subscribers, to volume 50, 2016 is $£$ 500 net (US $\$ 878$ in the USA, Canada, and Mexico) for institutions. Individuals who order direct from the publishers and certify that the journal is for their personal use may subscribe at a reduced rate of $£ 80$ for print (US \$1 37 in the USA, Canada, and Mexico). Single parts cost $£ 92$ (US \$162 in the USA, Canada, and Mexico). The electronic only price available to institutional subscribers is $£ 423$ (\$740 in the USA, Canada, and Mexico). All orders must be accompanied by payment. EU subscribers (outside the UK) who are not registered for VAT should add VAT at their country's rate. VAT registered subscribers should provide their VAT registration number. Japanese prices for institutions are available from Kinokuniya Company Ltd, P. O. Box 55, Chitose, Tokyo I56, Japan.

Periodicals postage paid at New York, New York and additional mailing offices. POSTMASTER: send address changes in the USA, Canada, and Mexico to MODERN ASIAN STUDIES, Cambridge University Press, ioo Brook Hill Drive, West Nyack, New York I0994-2I33, USA.

Information on Modern Asian Studies and all other Cambridge journals can be accessed via www.journals.cambridge.org

This journal issue has been printed on FSC-certified paper and cover board. FSC is an independent, non-governmental, not-for-profit organization established to promote the responsible management of the world's forests. Please see www.fsc.org for information. 